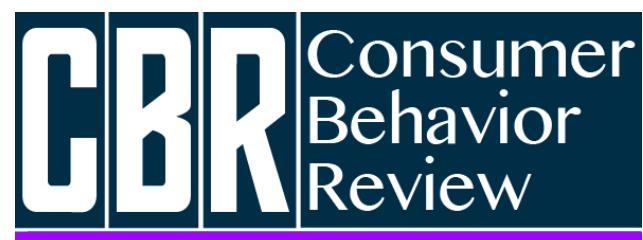

Revista Comportamento do Consumidor
Paula, B. A. S., Farias, L. F., Farias, S. A., \& Silva, I. M. M. (2020). In the Purchase's Essence: Sensory and symbolic elements in the descriptions of perfume sales over the Internet. Consumer Behavior Review, 4(3), 217-228.
ISSN: 2526-7884

Editor: Prof. Dr. Marconi Freitas da Costa Journal's e-mail: cbr@ufpe.br
Evaluation: Double blind review

Received: March 13, 2020

Accepted: May 19, 2020

\title{
IN THE PURCHASE'S ESSENCE: SENSORY AND SYMBOLIC ELEMENTS IN THE DESCRIPTIONS OF PERFUME SALES OVER THE INTERNET
}

Na essência da compra: elementos sensoriais e simbólicos nas descrições de vendas de perfumes

pela internet

\author{
Brenda Allana Santos de Paula ${ }^{1}$ \\ ORCID: https://orcid.org/0000-0002-4662-9774 \\ E-mail: brendaa7santos@gmail.com \\ Miriam Leite Farias ${ }^{1}$ \\ ORCID: https://orcid.org/0000-0002-3207-9900 \\ E-mail: miriamlfarias@gmail.com \\ Salomão Alencar de Farias ${ }^{2}$ \\ ORCID: https://orcid.org/0000-0001-5415-2606 \\ E-mail: saf@ufpe.br \\ Ilda Maria Moraes e Silva ${ }^{1}$ \\ ORCID: https://orcid.org/0000-0001-6296-7514 \\ E-mail: ildam.moraes@gmail.com
}

\begin{abstract}
${ }^{1}$ Programa de Pós-Graduação em Administração, Universidade Federal de Pernambuco, Recife, Brazil ${ }^{2}$ College of Business, Georgia State University, Atlanta, United States of America
\end{abstract}

\begin{abstract}
This study aimed to analyse whether sensory and symbolic elements used in perfume descriptions in internet sales can positively influence the level of involvement and consumer buying intention. To do so, a quasi-
\end{abstract}

\begin{abstract}
Resumo
Este estudo teve o objetivo de analisar se elementos sensoriais e simbólicos utilizados nas descrições de perfumes em vendas pela internet podem influenciar positivamente o nível de envolvimento e intenção de compra
\end{abstract}


experimental design was adopted with the creation of three scenarios: one control group and two experimental groups. Each participant was presented to only one of the scenarios created, characterizing the model between subjects. Regarding the results, it was found that it is not possible to perceive differences between the means of the groups in relation to the dependent variables, except for a negative association between sensory aspects and the level of involvement. Therefore, it was concluded that it may not be advantageous to invest in sensory and symbolic aspects present in the product description in internet sales, it is necessary to rethink this strategy due the fact that this environment has a certain limitation with hedonics products.

Keywords: Sensorial marketing; Symbolic consumption; Perfumes; Online sales. do consumidor. Para tanto, adotou-se um desenho quase experimental com a criação de três cenários: um grupo de controle e dois grupos experimentais. Cada participante foi apresentado a apenas um dos cenários criados, caracterizando o modelo between subjects. Quanto aos resultados, verificou-se que não é possível perceber diferenças entre as médias dos grupos com relação às variáveis dependentes, com exceção de uma associação negativa entre aspectos sensoriais e o nível de envolvimento. Portanto, concluiu-se que talvez não seja vantajoso investir em aspectos sensoriais e simbólicos presentes na descrição do produto em vendas pela internet, é necessário repensar essa estratégia tendo em vista que esse meio possui certa limitação com produtos hedônicos.

Palavras-chave: Marketing sensorial; Consumo simbólico; Perfumes; Vendas online.

This work is licensed under a Creative Commons Attribution 4.0 International License.

\section{INTRODUCTION}

The act of consumption of goods and services not only occurs from a functional perspective, but also through the personal and social meanings to which they are associated, characterizing a symbolic consumption. In this case, a symbol would be appropriate and influence the consumer's decision-making by acting consistently with the image that the person makes of oneself or what would desire to be (Levy, 1959; McCracken, 1986; Arnould \& Thompson, 2005, 2007). Therefore, the use of the symbolic dimension in marketing aims to better understand and explore the consumer thoughts and behaviours (Schmitt, 1999; Yang, 2019). It is a way for organizations to stand out in the face of competitiveness in the market.

To explore the symbolic aspects of the products, the companies constantly use sensory marketing. Sensory strategies seek to clarify the identity and values of a brand not only by functional aspects, but through emotional and psychological elements, creating subconscious triggers for the consumer perception of the abstract aspects of the product, such as elegance, sensuality, and modernity, for example (Krishna, 2012).

Hence, sensory marketing involves the five natural senses of the consumers, affecting their perceptions, judgments and behaviours. The reason for a company to emphasize in sensory aspects would be to distinguish a brand from other competitors, especially when rational attributes, such as price or quality, are similar (Hultén, 2011; Krishna, 2012).

It is necessary to recognize the resources brought by consumers in the interaction with the context during the creation of the experience, as well as their feelings and the meanings involved (Scussel, 2019). These various aspects of the customer experience (cognitive, emotional, sensory, pragmatic and relational) have the ability to contribute to customer involvement, having a favourable impact on the purchase intention (Altschwager et al., 2017; Su, Lu \& Lin, 2018; Leong et al., 2019).

Sensory stimuli, such as the choice of colours, lighting, music, aromas, textures and flavours, help in the composition of the store atmosphere. By being present in physical environments, these elements become relevant to the extent that they can influence the perception and behaviour of customers (Aguiar \& Farias, 2014).

However, although this theme has evolved a lot from studies focused on the effects of colours, touch, music, aroma and lighting on the purchase's behaviour (Barbosa \& Farias, 2014; Campos, 
Santos \& Vilhena, 2020), the interest in understanding the influence of sensory stimuli on consumer behaviour had predominantly turned to physical environments.

By expanding the physical store environments to virtual platforms or websites, companies in many segments face limitations in delivering these outstanding customer experiences. Often, the artifice employed involves the use of symbolism through images, as well as texts and descriptions that accompany the advertising of products. This is the case, for example, of the marketing of perfumes over the Internet. It has become quite common for the product description to be made in such a way as to evoke the senses (involving visual indications such as colours and shape of the bottle (Kotler, 1974), and verbal, with the sensory description of olfactory stimuli), relating to symbolic dimensions, such as the identity and personality of the target audience.

In a study conducted by Toncar and Fetscherin (2012) about fragrance advertisements, the authors make comparisons between the expectations arising from sensory stimuli and the actual evaluations of perfumes, highlighting how much consumer fantasy is explored (symbolic dimensions) and induced a certain mood, through visual and verbal tactics, including metaphors and language figures.

It is also noteworthy the relevance of the perfumery and cosmetics sector in the Brazilian economy. According to the data from the Brazilian Association of Personal Hygiene, Perfumery and Cosmetics Industry, the country occupied the 4th position in the world ranking in 2019 (Abihpec, 2020), and catalogue and online sales are extremely relevant in this business. The arrival of major retailers such as Sephora in Brazil, selling both in physical and virtual stores, increases competitiveness and brings challenges to attract and sell their products to consumers.

Therefore, it is relevant to investigate whether the allusion to sensory and symbolic aspects, through the description and images of the products, can cause influence or can contribute to the level of involvement and decision-making of the consumer's purchase intention. Exposed this, the present study sought to answer the following research question: Can the sensory and symbolic elements used in perfume descriptions in internet sales positively influence the level of consumer involvement and purchase intention in relation to the product?

Thus, this study aims to bring as theoretical contributions: the theorization of sensory and symbolic marketing in online sales strategies; and as practices/management contributions: a better understanding of the effects and implications of this strategy in this type of environment. Contextualized the research problem, the literature review and the methodological procedures are presented below. Subsequently, the analyses and discussions of the results are described, ending with the conclusions and references used for this study.

\section{LITERATURE REVIEW}

\section{Symbolic Dimension of Consumption}

Consumption consists of an activity that belongs to a system of symbols in which products are acquired not only for their functional functions, but for their socially acquired meanings. The symbols represent the construction and definition of the social reality, besides influencing consumer behaviours (Levy, 1959; Hirschman, 1981; Baudrillard, 2016). In this sense, Santos (2012) states that objects assume an adjective character, because they have signs, and thus the connection with a given article confers a symbology to its owner, due the representative culturally shared value circulating among individuals.

Lee (2013) defined symbolic consumption as individuals buying specific products and using the meanings behind these products to convey a certain image of themselves. Therefore, consumers, when making a purchasing decision, should analyse similar product types, designs, prices and, most importantly, the symbolic value behind the products. Symbolic consumption is widespread in daily life through advertising (Yang, 2019).

Hirschman (1981) points out that the phenomenon of symbolic consumption happens especially when it reinforces the identity of the consumer. Consumption is related to the consumer's desire to achieve their best version, reinforcing what each person would like to improve on himself (Levy, 1059). For Campbell (2004), this expectation can come from the subject's past experiences with 
the product, since memory is evoked and leads to believe that there will be greater pleasure if an experience lived in the past is repeated.

Holbrook and Hirschman (1982) argue that consumption involves emotional, symbolic, sensory, hedonic, and aesthetic factors, thus constituting an experiential view. The idea of creating a consumer experience came about with the possibility of the user connecting directly with the brand and creating an emotional and personalized relationship (Romo \& Segura, 2020). Thus, with technological evolution and increasing competition, the functional aspects of the products become similar, with the need for brands to try to stand out through intangible, relational and experiential attributes (Ditoiu \& Caruntu, 2013).

From the point of view of marketing strategies in the revised literature, symbolic consumption refers to the choice of products and brands (Ger \& Belk, 1996; McCracken, 1986; Han, Nguyen \& Simkim, 2016; Parker, Sams \& Jeans, 2018), in how, for example, its symbolism has a positive effect on brand loyalty (Ekinci, Sirakaya-Turk \& Preciado, 2013; Tangsupwattana \& Liu, 2018). It also relates to topics such as active self-creation of consumers (Luna-Cortés, 2017) and conspicuous consumption (Kim \& Jang, 2014).

Shang, Chen and Huang (2012) addressed the influence of symbolic consumption on consumer buying intention in the virtual world. However, despite all these contributions of the authors mentioned above, it is still incipient what is known about the effects of symbolic consumption in the online environment, especially when related to products that also offer sensory marketing strategies to compose the consumer experience.

\section{Sensorial Marketing}

Sensorial marketing occurs with the use of stimuli and elements that consumers perceive through the senses to generate certain atmospheres (Gómez \& García, 2012; Singhal \& Khare, 2015). For Krishna (2012), by involving the senses, sensory marketing affects consumer perceptions, judgments, and behaviours. As more sensory stimuli you have, the more effective and unforgettable the experience will be (Pine II \& Gilmore, 1998).

The creation of new sensations or the emphasis on existing sensations can increase the appeal of goods and services, resulting in the generation of desirable brand attributes stronger and more efficient than those provided only verbally by advertising. A priority for companies is to implement marketing strategies focused on creating memorable sensations and experiences for consumers, trying to create unique moments for their clients (Gómez-Suárez \& Schmitz, 2020).

As Lindström (2006) points out, we also seek to establish a connection between the consumer and the brand on an emotional level, through the interaction of the five human senses in the process, seeking to attract clients in a differentiated way. The awakening of emotions tends to generate higher level of involvement, which remain longer in the consumer's mind

For Singhal and Khare (2015), sensory marketing is part of the stimuli that affect the senses, and how the consumer interprets, understands, and responds to these stimuli. And if used appropriately, this marketing strategy can influence the consumer's decision. This view is aligned with the stimulus-organism-response paradigm advocated by Mehrabian and Russell (1974), in which a stimulus triggers an affective state in the consumer, which, in turn, generates behaviours.

Sensory aspects can also influence the consumer's decision through the creation of mental associations, strengthening the recall of brands and products and creating or modifying perceptions of quality (Rimkute et al., 2016). It plays an important role in judgment because bodily experiences and feelings act as a source of information, since one cannot understand human cognition without considering that human beings interact with the world through their senses and body. Consequently, human cognition is based on the sensory experience resulting from interaction with the world (Krishna \& Schwarz, 2014).

The general perception of the consumer about a product is a multisensory process, in which the associations come from the cognitive process, based on sociocultural concepts. Therefore, "the product with its specific sensory characteristics has a specific semantic meaning and, therefore, is 
perceived by consumers as a symbolic object that defines the identity of the consumer" (Favalli, Skov \& Byrne, 2013, p. 186).

According to the conducted review of preview studies, research relating sensory marketing strategies are increasingly focused on the management and development of points of sale, that is, how to use properly these strategies in the physical environment of a company to create an atmosphere that positively influences the consumer's purchasing decision. For example, Silva et al. (2017) verified which sensory marketing tools are used in a chocolate shop and whether consumers would be influenced by them. The work of Sausen et al. (2019) focused on the showcases and internal environments of children's fashion stores. The idea of sensory marketing was also found from the understanding of the retail atmosphere as an effort to generate a shopping experience among individuals with visual deficiency (Souza et al., 2019). As Gorlich (2015) points out, a pleasant and pleasurable store environment, suitable for dynamic consumer movement, strongly influences purchasing behaviour.

Sometimes, the researchers went through the physical environment of the store and analysed the sensory marketing under the need to better understand the experience of the senses in relation to the products (Carneiro \& Bezerra, 2019; Romo \& Segura, 2020), or the consumer experience itself (Ortegón-Cortázar \& Rodriguez, 2016; Agapito et al., 2016; Mosque, 2016). Therefore, it is considered that this study becomes relevant by analysing the influence of sensory marketing in online environments in addition to the idea of symbolism of the product announced in advertising, something that has not yet been found in previous works on the subject.

Finally, considering that the sales of perfumes over the Internet, above all, the meanings of vision (attractive and symbolic images) and smell (olfactory description of the fragrance), it is important to analyse how these meanings are perceived in the literature. Ditoiu and Caruntu (2013) explain that a more visually attractive product can more easily arouse consumer interest and attention. According to Spence et al. (2014), visual stimuli generally have direct positive effects on the buying behaviour, affecting people's mood and emotional state. This fact is related to the existence of aesthetic preferences, in which there is a tendency to select those more pleasant and stimulating.

For the author, visual indications can trigger specific associations in consumers that can facilitate decision-making, since different meanings are often attributed to each colour (Spence et al., 2014). Spence (2012) suggests that it is possible to improve consumer experiences with products by ensuring that the shape of the packaging establishes sensory expectations congruent in the consumer's mind.

In addition to vision, the smell also acquires importance, since no other sensory system makes such direct and intense contact with the neural substrates of emotion and memory (Herz \& Engen, 1996). Krishna (2012) emphasizes the human capacity to recognize and differentiate smells, with the possibility of evoking autobiographical memories. Also, the aroma of a product increases memory for associated information. On the association between odour and emotion, Gulas and Bloch (1995) argued that affective responses to aroma are influenced by the consumer's olfactory preferences, although there are those universally considered pleasant or not. Bone and Jantrania (1992) suggested that reactions to olfactory stimulus are influenced by the congruence between it and other product characteristics.

Having briefly explained the literature in relation to symbolic consumption and sensory marketing in consumer behaviour, the next topic will include the dependent variables of the research: level of involvement and purchase intention.

\section{Level of consumer involvement and purchase intent}

Chalil and Dharmmesta (2015) argue that consumer involvement is a form of evaluation that precedes the consumption of a product, i.e. a person's motivation to perform recovery, information processing and decision-making about a product or brand, also having an impact on loyalty formation. Leong et al. (2019) observe it as a multidimensional construct, which encompasses aspects such as: perceived importance (compatibility with the individual's goal, personal interest and meaning); 
pleasure (hedonic and emotional value), sign (symbolic value, associated with individual social status, personality and identity) and risk (possibility of unwanted repercussion).

Berger and Milkman (2012) and Martins et al. (2019) argue that there are several reasons behind why people engage with certain content. The first is to contain useful information. Another is the evocation of emotions or entertainment, capable of generating a state of excitement or activation, which corresponds to mobilization, generating behaviours related to action. Thus, it was demonstrating by the authors that practically useful, interesting, and surprising content is more engaging. Additionally, the personalization of messages is of great prominence, since it has a positive impact on how consumers respond to marketing communications, and engagement is an extension of the way they relate the message to themselves (Cruz, Leonhardt \& Pezzuti, 2017).

In a study by Yang, Min and Garza-Baker (2019), it was found that involvement levels can be used for segmentation of customers and development of different marketing strategies. Therefore, the effectiveness of advertising actions and the attitudes, motivations, interest and behavioural intentions of consumers are impacted by the variable level of involvement. Leong et al. (2019) state that involvement is the antecedent of engagement, being able to influence emotional attachment and subsequent interactions with the brand or product (Cruz, Leonhardt \& Pezzuti, 2017). Zhang and Yoon (2018) found that the way content is presented, and the level of consumer involvement influence the final adoption of the product, and this is mainly related to changes in consumer purchasing attitudes and intentions. For the authors, people tend to better process and memorize information when mental images are activated, usually by joining image and text. Also, individuals with high involvement will pay more attention to the arguments made, the increase the likelihood of welcoming them.

When products are emotional (e.g., perfumes), subjective and evaluative arguments are more effective. In this sense, the level of consumer involvement moderates the effect of the presentation of the content on the adoption of the product. Rahbarian and Meshkani (2014) and Chalil and Dharmmesta (2015) also indicated that consumer involvement has a positive and strong relationship with purchase intention, as well as a positive relationship between advertising engagement and product engagement.

Martins et al. (2019) point out that the purchase intention indicates the likelihood that consumers will plan or are willing to buy a particular product or service. The higher the intention, the greater the chance of the purchase being effected. To have a positive purchase intention, the brand must provide an engagement, positive involvement. They also say that ads play an increasing role in the buying decision-making process and therefore must considerate the determinants to be well accepted by customers and have the desired trigger effects. In this case, the purchase intention is portrayed as a consequence of the value of advertising, customer experience, quality of design and brand recognition.

According to $\mathrm{Su}, \mathrm{Lu}$ and Lin (2018), the purchase intention is affected by cognitive and affective aspects, which generate responses in consumers, and affective ones have the greatest effect. These results suggest that the extent of consumers' emotional reaction to persuasive messages has a particularly important influence on purchase intent in story-based advertising. Yang et al. (2018) visualized that the concept of identity has a positive relationship with consumer purchase intentions. According to them, psychology and marketing studies have shown that consumers, when making purchasing decisions, are affected by their reference social groups, in the search for a sense of identification with the community. They take into account values perceived significantly and the search for improvement of their self-image and distinction from others.

Altschwager et al. (2017) discuss the relationship between consumer involvement and purchase intention. They argue that creating unique and memorable experiences can have a favourable impact on purchase intent. The customer experience involves diverse components: a) cognitive (require the participant to actively think, or aim to stimulate conscious mental processes in a specific area of interest); b) emotional (evoke an affective response and aim at feelings and / or emotions); c) sensory (provide positive sensory stimulation, increasing the particular senses of vision, hearing, touch, taste and / or smell, which, by their very nature, makes them actively participate in the experience); d) pragmatic (require behaviours or physical actions of the client); and e) relational (emphasize the 
social context and relationships with others). A single event can contain one, several, or all experimental components to varying degrees, and each one can contribute to customer engagement.

According to discussion made in the literature review so far, it is understood that the sensory and symbolic aspects contribute to improve the customer experience, which can positively impact the level of involvement and, in consequently, the consumer's purchase intention. With this, this study aimed to test the following hypotheses presented below:

H1: sensory aspects present in the product description have a positive association with the level of consumer involvement.

H2: sensory aspects present in the product description have a positive association with the consumer's purchase intention.

H3: symbolic aspects present in the product description have a positive association with the level of consumer involvement.

H4: symbolic aspects present in the product description have a positive association with the consumer's purchase intention.

\section{METHOD}

The present study is quantitative in nature, fitting as a quasi-experiment carried out in the field. In experiments, independent variables are manipulated to verify the effect produced on the dependent variable, while strange variables are controlled (Cooper \& Schindler, 2011; Hernandez, Basso \& Brandão, 2014). The quasi-experiment is usually used when we do not have sufficient control of the variables of the experimental treatment (Cooper \& Schindler, 2011) and lack of randomness in the process of distribution of the subjects (Cook, Campbell \& Shadish, 2002).

Experimental research in Social Sciences are usually quasi-experiments, considering the impossibility of fully controlling the intervening variables (Goslin \& Gonçalves, 2004). Therefore, this method is already legitimated and used in research in the field of marketing (Smith, 2006; Debruyne, Frambach \& Moenaert, 2010).

The choice of participants followed a non-probabilistic sampling criterion, considering the determinant factor that individuals had already purchased perfume at some point in their lives. Before the data collection, a pre-test of the research instrument was performed with 100 students from a Federal Public University. After the necessary corrections were made, the questionnaires were applied. It is worth mentioning that the participants did not receive any kind of incentive or reward to participate in the study, and that only the researchers applied the questionnaires, there was no help from third parties. Data collection was performed at the premises of two public institutions of higher education and in a shopping center, both places are in the Northeast region of Brazil. In addition to the face-to-face approach of collect data, the questionnaires were also applied online, performing the Mann-Whitney $U$ test to verify the similarity of the distributions of the independent samples.

At the end of the treatment, 332 valid questionnaires were obtained, 113 from the Control Group (CG), 109 from Experimental Group 1 (EG1) and 110 from Experimental Group 2 (EG2).

\section{Research scenarios}

Three scenarios were created for the application of the research: one for the Control Group (CG), the other for Experimental Group 1 (EG1) and the last for Experimental Group 2 (EG2). All groups received the questionnaire containing a real advertisement for a perfume marketed on the Sephora website. The three groups were exposed to the fragrance image. In addition to the image, the CG analysed a generic description of the perfume. The EG1 analysed the sensory description and the EG2 the symbolic description of the perfume. With this, it was aimed to explore the existence of difference between the descriptions presented in relation to the ability to influence the level of involvement and intention of purchase of the consumer. Each participant evaluated only one scenario, characterizing the quasi-experiment model as between-subjects, in which different individuals are exposed to different treatments (Lehmann \& Gupta, 1999). 
The ad was chosen intentionally, giving preference to unisex models that could be evaluated by both sexes. It is emphasized that the brand of the perfume was erased with Photoshop so it would not to influence the responses of the participants and, also that there was a filter question in the questionnaire where only continued answering the participants who said they did not know the ad in question. After analysing the advertisement that contained the perfume image and the referring description of each group, the participants filled out the questionnaire with the measurements of the dependent variables (involvement and purchase intention) in addition to a part with variables related to their sociodemographic profile.

\section{Research variables and data collection instrument}

For the operationalization of the study, it was sought to compare the evaluations of the different scenarios of the quasi-experiment by measuring two constructs: involvement and purchase intention of the consumer. Regarding the degree of involvement, the revised Scale of Personal Involvement Inventory (Zaichkowsky, 1994) was used, which constitutes a semantic differential scale composed of 10 items in two cognitive and affective dimensions. On the other hand, the purchase intention was measured by adapting the 5-point scale (Meilgaard, Civille \& Carr, 1999), to a 7-point scale ( 1 =certainly would not buy, $7=$ certainly would buy).

The final questionnaire contained questions related to perfume purchases and specifically about the frequency of perfume purchases over the Internet, the scales that measured the dependent variables (involvement and intention to purchase) and five variables to raise the demographic profile of respondents (gender, age, individual income, education and profession). Of the 372 questionnaires applied, about 40 of them were considered invalid for the research and they were discarded, either because they did not meet the filter question, already knowing the perfume, or by incomplete answers. Then, 332 were considered valid, which were numbered, and their answers were codified and analysed.

Regarding the operationalization of the variables, normality tests, exploratory factor analysis and Cronbach's alpha coefficient were calculated. The collected data were submitted to descriptive statistical tools and hypothesis tests and the analysis was carried out with the help of the statistical package SPSS- 25.0 (Statistical Package for Social Sciences)

\section{RESULTS}

\section{Profile of the participants}

The demographic variables explored to know the characteristics of the sample were gender, age, individual monthly income, level of education and profession. Considering the total sample of the three groups, $61.1 \%$ were women and $38.9 \%$ men. They are young people with a mean age of approximately 26 years (d.p. $=9.1$ ), mostly students $(45.5 \%)$ with graduation in progress $(77.9 \%)$. Regarding individual monthly income, 262 responses were obtained, with an average of $\mathrm{R} \$ 2,245.19$ and (d.p. = 2,954), ranging from $R \$ 100.00$ to $R \$ 20,000.00$. Of these respondents, $71.8 \%$ said they had never bought perfumes over the internet, while $28.2 \%$ said they had bought at least once. Table 1 shows the sociodemographic characteristics specific to each group.

Table 1

Comparison between the sociodemographic profiles of each group

\begin{tabular}{l|l|c|c|c}
\hline \multicolumn{2}{l|}{ Sociodemographic Characteristics } & Control Group & $\begin{array}{c}\text { Experimental } \\
\text { Group 1 }\end{array}$ & $\begin{array}{c}\text { Experimental } \\
\text { Group 2 }\end{array}$ \\
\hline \multirow{3}{*}{ Gender } & Female & $62,80 \%$ & $57,8 \%$ & $67,2 \%$ \\
\cline { 2 - 5 } & Male & $37,2 \%$ & $42,2 \%$ & $37,3 \%$ \\
\cline { 2 - 5 } & N & 113 & 109 & 110 \\
\hline \multirow{2}{*}{ Age } & Mean & 28,04 & 25,02 & 24,52 \\
\cline { 2 - 5 } & SD & 12,22 & 6,01 & 7,36 \\
\hline
\end{tabular}




\begin{tabular}{l|l|c|c|c}
\hline & $\mathrm{N}$ & 112 & 106 & 109 \\
\hline \multirow{3}{*}{$\begin{array}{l}\text { Individual Monthly } \\
\text { Income (R\$) }\end{array}$} & Mean & $2.601,41$ & $2.144,62$ & $1.481,39$ \\
\cline { 2 - 5 } & $\mathrm{SD}$ & $3,114.10$ & $2.967,45$ & $2.510,23$ \\
\cline { 2 - 5 } & $\mathrm{N}$ & 94 & 95 & 95 \\
\hline \multirow{3}{*}{ Education Level } & $\begin{array}{l}\text { Graduation in } \\
\text { course }\end{array}$ & $36,6 \%$ & $63,9 \%$ & $74,1 \%$ \\
\cline { 2 - 5 } & $\mathrm{N}$ & 112 & 108 & 108 \\
\hline \multirow{2}{*}{ Profession } & Student & $43,4 \%$ & $45 \%$ & $48,2 \%$ \\
\cline { 2 - 5 } & $\mathrm{N}$ & 113 & 109 & 110 \\
\hline
\end{tabular}

Source: Data from the research (2020)

\section{Analysis of sample distribution}

To test the adherence of the sample, the Kolmogorov-Smirnov (K-S) test (Malhotra, 2006) was used. The scales of involvement (10 items) and purchase intention ( 1 item) were analysed. The result of the adherence test was significant $(\mathrm{p}<0.05)$ for the scales analysed, rejecting the null hypothesis of normal distribution for all variables analysed. Thus, the use of nonparametric techniques for data analysis is indicated.

\section{Validity and reliability of constructs}

The validity and reliability of the involvement scale were determined by exploratory factor analysis and Cronbach's alpha coefficient. Because it has only one item, the purchase intent scale has not been tested. Factor analysis aims to define the internal structure inherent between the variables of the analysis (Hair et al., 2009). For this, the Kaiser-Meyer-Olkin test (KMO) was performed, which indicates the degree of explanation of the data based on the factors found in the factor analysis. Bartlett's scouting test indicates whether there is a sufficient relationship between the indicators (Corrar, Paulo \& Dias Filho, 2007). In the involvement scale, the KMO resulted in $0.9, \chi^{2}=2847.22$ with 55 degrees of freedom and significance level $\mathrm{p}<0.05$. Thus, the scale of involvement presented adequacy for the application of factor analysis. In the involvement scale, two factors were obtained, but $65.21 \%$ of the variance were explained by only one factor that contained five items (tedious, exciting, attractive, fascinating, and engaging). Thus, we chose to determine a new variable that would include involvement using only these items on the scale.

In order to ensure the reliability of the data, Cronbach's alpha coefficient was calculated, which assesses the internal consistency of the scales, and should not exceed the lower limit of 0.7 (Hair et al., 2009). The tests for the involvement scale $(\alpha=0.92)$ showed satisfactory reliability results according to the literature.

\section{Analysis of means, hypothesis tests and discussion of results}

Analysing Table 2, it is possible to notice that the mediums of the scales were relatively low. The variable that, in general, presented higher means was level of involvement, followed by purchase intention. Furthermore, the best evaluations alternated between CG and EG2 (symbolic), with minimal difference between them. The group with the lowest evaluation in all aspects was EG1 (sensory).

Table 2

Means of variables per group

\begin{tabular}{lccccccc}
\hline & & \multicolumn{2}{c}{ Control Group } & \multicolumn{2}{c}{ EG1 (sensorial) } & \multicolumn{2}{c}{ EG2 (symbolic) } \\
\hline Variables & Factorial & Mean & SD & Mean & SD & Mean & SD \\
Involvement & & 3,48 & 1,53 & 2,79 & 1,446 & 3,49 & 1,440 \\
Interesting & 0,782 & 4,07 & 1,756 & 3,26 & 1,607 & 3,94 & 1,85 \\
Exciting & 0,840 & 3,62 & 1,723 & 3,06 & 1,557 & 3,83 & 1,641
\end{tabular}




\begin{tabular}{llllllll} 
Attractive & 0,838 & 3,87 & 1,703 & 3,25 & 1,777 & 3,9 & 1,693 \\
Fascinating & 0,830 & 3,65 & 1,772 & 3,05 & 1,583 & 3,42 & 1,541 \\
Engaging & 0,813 & 3,65 & 1,821 & 2,97 & 1,536 & 3,86 & 1,789 \\
\hline Purchase Intention & & 3,27 & 1,583 & 2,84 & 1,594 & 3,24 & 1,477 \\
\hline
\end{tabular}

Source: Data from the research (2020)

However, it was necessary to use variance analysis (ANOVA) to ascertain the statistical significance of the difference between groups (Hair et al., 2009). Thus, it was aimed to evaluate whether the use of sensory and symbolic descriptions in the sales of perfumes over the Internet can positively influence the level of involvement and intention of purchasing the product. This method was used to test the null hypothesis that the means of the groups for each of these constructs are equal (Cooper and Schindler, 2011). For comparison, the significance level was specified in $\mathrm{p}<0.05$ (Smith, 2006). Analysing Table 3, it is possible to notice that regarding the level of involvement (H1 and H3), there was a difference between the means of the three groups $(p=0.000)$, but, comparing each of the experimental groups with the control group, only the difference in the mean of the first group was significant $(\mathrm{p}=0.003)$ (Table 4$)$.

Table 3

Test ANOVA of level of involvement $\mathrm{H}_{1}$ and $\mathrm{H}_{3}$

\begin{tabular}{lccccc} 
& $\begin{array}{c}\text { Sum of } \\
\text { Squares }\end{array}$ & DF & $\begin{array}{c}\text { Mean } \\
\text { Square }\end{array}$ & F & P-valor \\
\hline Between Groups & 33,934 & 2 & 16,967 & 7,807 & 0,000 \\
Within Groups & 691,119 & 318 & 2,173 & & \\
Total & 725,053 & 320 & & & \\
\hline
\end{tabular}

Levene statistics $=0,293 / \mathrm{p}=0,746$

Source: Data from the research $(2020)$

Table 4

Test Scheffe of multiple comparations of the involvement level $\left(\mathrm{H}_{1}\right.$ e $\left.\mathrm{H}_{3}\right)$

\begin{tabular}{llc} 
Groups & & Sig. \\
\hline CG & EG1 (sensorial) & 0,003 \\
& EG2 (symbolic) & 0,998 \\
\hline
\end{tabular}

Source: Data from the research (2020)

Thus, regarding the hypotheses raised, $\mathrm{H} 1$ considered that sensory aspects have a positive association with the level of consumer involvement with the product. Because the existence of differences between the CG and the EG1 was verified, it is understood that the sensory aspects can influence the level of consumer involvement. However, since EG1 presented lower means than CG, it is noted that sensory aspects have a negative association with the level of involvement. That is, contrary to what was expected, people who were submitted to sensory description had a lower level of involvement than those who had access to a generic description of the product, rejecting H1.

In this sense, when considering the description of the sensory aspects of perfume presented in Experimental Group 1, a significant decrease in the mean of the variable involvement was observed in relation to the medium of the other two groups. Hence, it may be interesting to note that some olfactory elements are not easily recognized or are difficult to imagine as components of a perfume (e.g., "wasabi", "wet paving stones"), and therefore it is complicated to identify the aromas and recall memories associated with previous experiences with other perfumes. Zhang and Yoon (2018) argue that for involvement it is necessary for people to properly process information, which is favoured when mental relationships are activated. Although some authors consider that the influence of smell on behaviour may occur unconsciously (Corbett, 2006), in circumstances of online commerce, that 
olfactory stimulus is present only through description, it is necessary that it be apprehended by the consumer (Gulas \& Bloch, 1995).

Ellis-Chadwick and Doherty (2012) indicate that marketing messages should be simple, brief, and concise to get an immediate response. The Ad text and layout are a potentially important execution tactics in online marketing because they play a decisive role in attracting attention and attracting consumers. However, interactive content, although it contributes to maintaining interest, so that they are more effective, need to be aligned with the needs of the recipients and be relevant to them. The results corroborate with what Cruz, Leonhardt and Pezzuti (2017) point out, in the sense that managers should carefully evaluate the construction and choice of words in their online messages, as consumers may consider some of them confusing and ignore others for judging them unimportant (Karakaya \& Saracli, 2018).

On the H3 hypothesis, that symbolic aspects have a positive association with the level of consumer involvement with the product, although EG2 had a higher mean than CG, which could indicate a higher level of involvement, the difference obtained was not substantial enough to be considered statistically significant, also rejecting H3. This absence of positive association may have occurred since in the acquisition of perfumes, consumers tend to seek fragrances congruent with the image with which they identify. Just as the content of the descriptions can represent a real/ideal projection of people, they also signal aspects that can generate aversion to consumption. The elements presented on the packaging or in the description of perfumes can generate association of people with a character that symbolically does not represent them, making it difficult to engage (Levy, 1959; Cruz, Leonhardt \& Pezzuti, 2017).

Like this, regarding the level of consumer involvement, it is suggested that the sensory elements and symbolic elements present in the product announcement in the online environment are not configured as positive influences. With regard to purchase intention, no significant differences were found between the means of the groups ( $p>0.05$ ) (Tables 5), i.e., it was not evidenced that sensory and symbolic elements had a positive association with the intention to purchase the product. The $\mathrm{H} 2$ and $\mathrm{H} 4$ hypotheses were also rejected. This is consistent with the findings of Rahbarian and Meshkani (2014) and Zhang and Yoon (2018), which indicate that the purchase intention is directly proportional and influenced by the level of involvement, and in this the differences between the groups were not significant to the point of affecting that. That is, the sensory and symbolic aspects present in the description of the perfume were not strong enough to create a memorable experience, in order to promote the identification and involvement of the client to the point of influencing the purchasing decision (Altschwager et al., 2017).

Table 5

ANOVA test of purchase intention $\left(\mathrm{H}_{2}\right.$ and $\left.\mathrm{H}_{4}\right)$

\begin{tabular}{lccccc} 
& $\begin{array}{c}\text { Sum of } \\
\text { Squares }\end{array}$ & DF & $\begin{array}{c}\text { Mean } \\
\text { Square }\end{array}$ & F & P-valor \\
\hline Between Groups & 12,482 & 2 & 6,241 & 2,59 & 0,077 \\
Within Groups & 792,699 & 329 & 2,409 & & \\
Total & 805,181 & 331 & & & \\
\hline Source: Data from the research (2020) & & &
\end{tabular}

Additionally, the Kruskal-Wallis nonparametric test for $\mathrm{K}>2$ independent samples was performed to verify the purchase intention results. It was observed the confirmation of the previous findings, that there is no difference between the means of the groups, with the rejection of the hypotheses H1 and H3. (p>0.05) (Table 6). 
Table 6

Test of hypotheses Kruskal-Wallis for purchase intention $\left(\mathrm{H}_{2}\right.$ and $\left.\mathrm{H}_{4}\right)$

\begin{tabular}{lccc}
\hline Variables & Qui-Square & DF & P-valor \\
\hline Purchase Intention & 5,364 & 2 & 0,068 \\
\hline
\end{tabular}

Source: Data from the research (2020)

To verify the results related to the level of involvement, it was necessary to perform the test of each experimental group alone, 2 to 2, considering that the results of significance of the mean difference were different for each group. Therefore, the Mann Whitney nonparametric test for $\mathrm{K}=2$ independent samples was used. Again, it was confirmed from the previous results (Table 7), that there is a significant mean difference only in EG1 (sensory) $(\mathrm{p}<0.05)$.

Table 7

Test of hypotheses Mann Whitney for level of involvement $\left(\mathrm{H}_{1}, \mathrm{H}_{3}\right)$

\begin{tabular}{lccc}
\hline \multicolumn{1}{c}{ Involvement } & $\begin{array}{l}\text { U Mann- } \\
\text { Whitney }\end{array}$ & $\mathbf{Z}$ & P-valor \\
\hline G1 (sensorial) & 4522,5 & $-3,188$ & 0,001 \\
G2 (symbolic) & 5654 & $-0,244$ & 0,807 \\
\hline
\end{tabular}

Source: Data from the research (2020)

\section{CONCLUSIONS}

Although the literature review points out that the exploration of sensory and symbolic aspects by marketing can positively influence the consumer (Rimkute et al., 2016), including in the online environment (Shang, Jin \& Qiu, 2020), the research results contradict these findings. It was not possible to verify this relationship in the level of involvement and intention of purchase in the decision of buying a perfume over the Internet, and, still, a negative association was found in the case of sensory elements in the level of involvement.

Therefore, the theoretical contribution of this study was to verify whether marketing strategies that are typically used in physical store environments can be also apply in online environments, with a view to the use of internet sales ads. Previous research focused on the impact of the influence of the senses on consumer behaviour (Agapito et al., 2016; Ballouli \& Bennett, 2014; Cirrincione, Estes \& Caru, 2014) and some authors sought to associate different sensory stimuli and other attributes of the product, as symbolic aspects (Lee \& O'Mahony, 2005; Aguiar \& Farias, 2014; Barbosa \& Farias, 2014). However, in these cases, stimuli were present concretely in purchasing situations in face-to-face environments. Thus, the findings discussed here are relevant, as they present a different approach, questioning whether it would be possible to obtain the expected results of sensory and symbolic marketing in relation to the level of involvement and intention of buying the consumer in online commerce. They also contribute to the addition in the discussions already brought by Shang, Chen and Huang (2012) and Shang, Jin and Qiu (2020), in the treatment of the hedonic characteristics of products in virtual environments.

Furthermore, it has as practical and managerial implications the analysis of the results of the strategies that companies and marketing professionals use in the sale of products online, verifying that some may not have the expected effect, especially in hedonic products with which it is not familiar. The perception of risk can exert interference, acting as moderator of the impact of sensory and symbolic elements on the level of involvement and purchase intention of the consumer. This is consistent with what Karakaya and Saracli (2018) say, when they comment that the involvement with the description will be due to the degree of perceived risk associated with the previous experience 
with the product (Martins et al., 2019). In online shopping situations, utilitarian and functional products are more likely to be justified as a good choice, while hedonics bring greater potential to arouse negative emotions, which interferes with purchase intention (Shang, Jin \& Qiu, 2020). Therefore, it is important to investigate the cost, risk vs. return ratio of each initiative.

This study has some limitations. One of them would be in relation to the use of questionnaires for data collection. This type of instrument may present problems such as the omission of important variables in the composition of a given construct. A second limitation would be in relation to the nonhomogeneity of the sample comparing the control group and the experimental groups, because the questionnaire was applied in different environments (universities and shopping center), besides being placed online. This represented a variation in the sample in relation to some variables, including income, age and level of education.

As suggestions for future research, it is necessary to conduct a qualitative study to investigate the interpretation of the sensory and symbolic aspects present in the descriptions of perfumes, which may better explain the reasons why these elements had no greater influence on awakening triggers for the level of involvement and intention of consumer purchase. Also, different perfumes can be used for the female and male audiences, performing segmentation, to provide greater adaptation to the personality of each one.

\section{References}

Abihpec (2020) - Associação Brasileira da Indústria de Higiene Pessoal, Perfumaria e Cosméticos, Mercado brasileiro de HPPC: quarta posição mundial com sensação de terceira. 2020. Disponível em: <https://abihpec.org.br/publicacao/panorama-do-setor-2019-2/a/>. Acesso em: 14 de fevereiro de 2020.

Agapito, D., Mendes, J., Pinto, P., \& de Almeida, H. (2016). The sensory dimension of consumer experiences in rural tourist destinations. Tourismos, 11(4).

Aguiar, E. C., \& Farias, S. A. D. (2014). Estímulos sensoriais e seus significados para o consumidor: investigando uma atmosfera de serviço centrado na experiência. Revista Brasileira de Marketing, 13(5), 65-77.

Altschwager, T., Conduit, J., Bouzdine-Chameeva, T., \& Goodman, S. (2017). Branded marketing events: engaging Australian and French wine consumers. Journal of Service Theory and Practice, 27(2), 336-357.

Arnould, E. J., \& Thompson, C. J. (2005). Consumer culture theory (CCT): Twenty years of research. Journal of consumer research, 31(4), 868-882.

Arnould, E., \& Thompson, C. (2007). Consumer culture theory (and we really mean theoretics): dilemmas and opportunities posed by an academic branding strategy. Research in consumer behavior, 11, 3 .

Ballouli, K., \& Bennett, G. (2014). New (sound) waves in sport marketing: Do semantic differences in analogous music impact shopping behaviors of sport consumers? Sport Marketing Quarterly, 23(2).

Baudrillard, J. (2016). The consumer society: Myths and structures. London: Sage.

Barbosa, O. T., \& de Farias, S. A. (2014). O Toque de Midas: Um Novo Olhar Sobre os Estímulos Táteis no Ambiente de Varejo. Revista Interdisciplinar de Marketing, 4(1), 17-32.

Berger, J., \& Milkman, K. (2012). What Makes Online Content Viral? Journal of Marketing Research, 49 (2), 192-205.

Bone, P. F., \& Jantrania, S. (1992). Olfaction as a cue for product quality. Marketing letters, 3(3), 289296.

Campbell, C. (2004). I shop therefore I know that I am: the metaphysical basis of modern consumerism. Elusive consumption, 27-44.

Campos, V. A., Santos, B. C., \& Vilhena, A. P. (2020). O Sabor irresistível: o marketing sensorial no comportamento de consumo do chocolate. Puçá: Revista de Comunicação e Cultura na Amazônia, 4(2). 
Chalil, R., \& Dharmmesta, B. (2015). The role of consumer involvement as a moderating variable: The relationship between consumer satisfaction and corporate image on service loyalty. Journal of Asian Scientific Research, 5(6), 303-319.

Cirrincione, A., Estes, Z., \& Carù, A. (2014). The effect of ambient scent on the experience of art: Not as good as it smells. Psychology \& Marketing, 31(8), 615-627.

Cook, T. D., Campbell, D. T., \& Shadish, W. (2002). Experimental and quasi-experimental designs for generalized causal inference. Boston, MA: Houghton Mifflin.

Cooper, D. R., \& Schindler, P. S. (2016). Métodos de Pesquisa em Administração-12ª edição. McGraw Hill Brasil.

Corbett, J. M. (2006). Scents of identity: organisation studies and the cultural conundrum of the nose. Culture and Organization, 12(3), 221-232.

Corrar, L., Paulo, E., Dias Filho, J. M., \& Rodrigues, A. (2011). Análise multivariada para os cursos de administração, ciências contábeis e economia.

Cruz, R., Leonhardt, J., \& Pezzuti, T. (2017). Second Person Pronouns Enhance Consumer Involvement and Brand Attitude. Journal of Interactive Marketing, 39,104116.

Debruyne, M., Frambach, R. T., \& Moenaert, R. (2010). Using the weapons you have: The role of resources and competitor orientation as enablers and inhibitors of competitive reaction to new products. Journal of Product Innovation Management, 27(2), 161-178.

Ditoiu, M. C., \& Caruntu, A. L. (2014). Sensory experiences regarding five-dimensional brand destination. Procedia-Social and Behavioral Sciences, 109(2), 301-306.

Ekinci, Y., Sirakaya-Turk, E., \& Preciado, S. (2013). Symbolic consumption of tourism destination brands. Journal of Business Research, 66(6), 711-718.

Ellis-Chadwick, F., \& Doherty, N. (2012). Web advertising: the role of e-mail marketing. Journal of Business Research, 65(1), 843-848.

Favalli, S., Skov, T., \& Byrne, D. V. (2013). Sensory perception and understanding of food uniqueness: From the traditional to the novel. Food research international, 50(1), 176-188.

Ger, G., \& Belk, R. W. (1996). Cross-cultural differences in materialism. Journal of Economic Psychology, 17(1), 55-77.

Gulas, C. S., \& Bloch, P. H. (1995). Right under our noses: Ambient scent and consumer responses. Journal of Business and Psychology, 10(1), 87-98.

Hair, J. F., Black, W. C., Babin, B. J., Anderson, R. E., \& Tatham, R. L. (2009). Análise multivariada de dados. Bookman Editora.

Han, S. H., Nguyen, B., \& Simkim, L. (2016). The dynamic models of consumers' symbolic needs: in the context of restaurant brands. European Journal of Marketing, 50 (7/8), 1348-1376

Hernandez, J., Basso, K., \& Brandão, M. (2014). Experimental research in marketing. Brazilian Journal of Marketing, 13(2).

Herz, R. S., \& Engen, T. (1996). Odor memory: Review and analysis. Psychonomic Bulletin \& Review, 3(3), 300-313.

Hirschman, E. C. (1981). Comprehending symbolic consumption: Three theoretical issues. ACR Special Volumes.

Holbrook, M. B., \& Hirschman, E. C. (1982). The experiential aspects of consumption: Consumer fantasies, feelings, and fun. Journal of consumer research, 9(2), 132-140.

Hultén, B. (2011). Sensory marketing: the multi-sensory brand-experience concept. European Business Review, 23(3), 256-273.

Karakaya, F., \& Saracli, S. (2018). Impact of perceived risk of food nutrients and serving size on consumer involvement with food labels. Nutrition \& Food Science, 48(4), p.549-560.

Kim, D., \& Jang, S. (2014). Symbolic consumption in upscale cafés examining Korean Gen Y consumers' materialism, conformity, conspicuous tendencies, and functional qualities. Journal of Hospitality \& Tourism Research, 41(2),154-179.

Kotler, P. (1973). Atmospherics as a marketing tool. Journal of retailing, 49(4), 48-64. 
Krishna, A. (2012). An integrative review of sensory marketing: Engaging the senses to affect perception, judgment and behavior. Journal of consumer psychology, 22(3), 332-351.

Krishna, A., \& Schwarz, N. (2014). Sensory marketing, embodiment, and grounded cognition: A review and introduction. Journal of consumer psychology, 24(2), 159-168.

Lee, E. J. (2013). A prototype of multicomponent brand personality structure: A consumption synmbolism approach. Psychology \& Marketing, 30(2), 173-186.

Lee, H. S., \& O'Mahony, M. (2005). Sensory evaluation and marketing: measurement of a consumer concept. Food Quality and Preference, 16(3), 227-235.

Lehmann, D. R., \& Gupta, S. S. JH (1999). Marketing Research. Reading, MA: Addison-Wesley.

Leong, M., Osman, S., Paim, L., \& Fazli, S. (2019). Enhancing consumer online engagement through consumer involvement: A case of airline and hospitality services in Malaysia. Management Science Letters, 9(6), 795-808.

Levy, S. J. (1959). Symbols for sale. Harvard Business Review, 37, 117-124.

Luna-Cortés, G. (2017). The influence of symbolic consumption on experience value and the use of virtual social networks. Spanish Journal of Marketing, 21(1), 39-51.

McCracken, G. (1986). Culture and consumption: A theoretical account of the structure and movement of the cultural meaning of consumer goods. Journal of consumer research, 13(1), 71-84.

Malhotra, N. K. (2006). Pesquisa de Marketing-: uma orientação aplicada. Bookman Editora.

Martins, J., Costa, C., Oliveira, T., Gonçalves, R., \& Branco, F. (2019). How smartphone advertising influences consumers' purchase intention. Journal of Business Research, 94, 378-387.

Meilgaard, M. C., Civille, G. V., \& Carr, B. T. (1999). Sensory evaluation techniques. CRC press.

Mehrabian, A., \& Russell, J. A. (1974). An Approach to Environmental Psychology, Cambridge, MA: MITPress.

Mesquita, C. S. S. (2016). Marketing sensorial: Estudo do impacto dos estímulos sensoriais na experiência em spas (Doctoral dissertation).

Ortegón-Cortázar, L., \& Rodríguez, A. G. (2016). Gestión del marketing sensorial sobre la experiencia del consumidor. Revista de Ciencias Sociales (Ve), 22(3), 67-83.

Parker, J. M., Sams, D., \& James, K. W. (2018). The Hedonic and Utilitarian Value of Volunteering as an Act of Symbolic Consumption: An Abstract. In Academy of Marketing Science Annual Conference (pp. 123-124). Springer, Cham.

Pine, B. J., \& Gilmore, J. H. (1998). Welcome to the experience economy. Harvard business review, 76, 97-105.

Rahbarian, H., \& Meshkani, F. (2014). Consumer involvement profiles: An application of consumer involvement in mobile industry. Management Science Letters, 4(4), 617-620.

Rimkute, J., Moraes, C., \& Ferreira, C. (2016). The effects of scent on consumer behaviour. International journal of consumer studies, 40(1), 24-34.

Romo, Z. F. G., \& Segura, C. P. (2020). La experiencia Nespresso, el Marketing Sensorial aplicado al sector del café. Miguel Hernández Communication Journal, (11), 75-96.

Santos, C. (2012). O poder simbólico do consumo: no trilho da gênese do discurso publicitário contemporâneo. Revista Comunicando, 1(1), 29.

Sausen, J. D. F. C. L., Bussler, N. R. C., Froemming, L. M. S., \& Baggio, D. K. (2016). Marketing sensorial no varejo de moda infantil. Seminário de Iniciação Científica, XXIV. Ijuí.

Schmitt, B. (1999). Experiential marketing. Journal of marketing management, 15(1-3), 53-67.

Scussel, F. B. C. (2019). Is Consumer Experience the Next Best Thing? Reflections from a systematic review and research agenda proposition. Consumer Behavior Review, 3(2), 57-69.

Sephora (2019). Disponível em: <http://www.sephora.com.br/>. Acesso em: 05 de julho de 2019.

Shang, Q., Jin, J., \& Qiu, J. (2020). Utilitarian or hedonic: Event-related potential evidence of purchase intention bias during online shopping festivals. Neuroscience Letters, 715.

Shang, R. A., Chen, Y. C., \& Huang, S. C. (2012). A private versus a public space: Anonymity and buying decorative symbolic goods for avatars in a virtual world. Computers in Human Behavior, 28(6), 2227-2235.

Singhal, S., \& Khare, K. (2015). Does sense reacts for marketing-Sensory Marketing. International Journal of Management, IT and Engineering, 5(5), 1-13. 
Smith, A. (2006). Assessing the contribution of flagship projects to city image change: a quasi-experimental technique. International Journal of Tourism Research, 8(6), 391-404.

Spence, C. (2012). Managing sensory expectations concerning products and brands: Capitalizing on the potential of sound and shape symbolism. Journal of Consumer Psychology, 22(1), 37-54.

Spence, C., Puccinelli, N. M., Grewal, D., \& Roggeveen, A. L. (2014). Store atmospherics: A multisensory perspective. Psychology \& Marketing, 31(7), 472-488.

Souza, I. B. M., Almeida, S., Lucian, R., \& Abreu, N. R. (2019). Sensorial merchandising: Um experimento no varejo de moda para inclusão de consumidores cegos. Revista de Empreendedorismo e Gestão de Pequenas Empresas, 8(1), 126-148.

$\mathrm{Su}, \quad$ P., Lu, H., \& Lin, P. (2018). How the microfilm marketing strategy stimulates consumers' purchase intention. Social Behavior and Personality: An International Journal, 46(6), 953(15).

Tangsupwattana, W., \& Liu, X. (2018). Effect of emotional experience on symbolic consumption in Generation Y consumers. Marketing Intelligence \& Planning, 36(5), 514-527.

Toncar, M., \& Fetscherin, M. (2012). A study of visual puffery in fragrance advertising. European Journal of marketing, 46(1/2), 52-72.

Yang, C. M. (2019). Influences of Product Involvement and Symbolic Consumption Cues in Advertisements on Consumer Attitudes. International Journal of Marketing Studies, 11(2).

Yang, J., Ma, J., Arnold, M., \& Nuttavuthisit, K. (2018). Global identity, perceptions of luxury value and consumer purchase intention: a cross-cultural examination. Journal of Consumer Marketing, 35(5), 533-542.

Yang, K., Min, J., \& Garza-Baker, K. (2019). Post-stay email marketing implications for the hotel industry: Role of email features, attitude, revisit intention and leisure involvement level. Journal of Vacation Marketing, 25(4), 405-417.

Zaichkowsky, J. L. (1994). The personal involvement inventory: Reduction, revision, and application to advertising. Journal of advertising, 23(4), 59-70.

Zhang, D., \& Yoon, S. (2018). Social media, information presentation, consumer involvement, and cross-border adoption of pop culture products. Electronic Commerce Research and Applications, 27, 129-138. 